\title{
Physical activity and academic performance in high school students
}

\section{Atividade física e desempenho acadêmico em estudantes de ensino médio}

\section{AUTHOR'S \\ Kelly Christine Maccarini Pandolfo ${ }^{1}$ (D) \\ Tatiane Minuzzi1 (D) \\ Cati Reckelberg Azambuja ${ }^{1}$ (D) \\ Daniela Lopes dos Santos ${ }^{1,2}$ (D) \\ 1 Universidade Federal de Santa Maria, Programa de Pós-Graduação em Educação Física/UFSM, Santa Maria, RS, Brasil. \\ 2 Universidade Federal de Santa Maria, Programa de Pós-Graduação em Educação Física. Departamento de Métodos e Técnicas, UFSM, Santa Maria, RS, Brasil.}

\section{CORRESPONDING}

Kelly Christine Maccarini Pandolfo

kellypandolfo@hotmail.com

Rua Irmã Maristela, 64. Santa Maria, RS, Brasil. CEP: 97060-273.

\section{DOI}

10.12820/rbafs.v.22n5p486-92

\section{(ब) $\Theta$}

Copyright: This is an open-access article distributed under the terms of the Creative Commons Attribution License ${ }^{\circledR}$, which permits unrestricted use, distribution, and reproduction in any medium, provided that the original author and source are credited.

\begin{abstract}
There are still doubts about the real benefits of physical activity on the academic performance of adolescents. The aim of this study was to determine whether the physical activity (PA) interferes in the academic performance of high school students. The study included 348 adolescents from one federal public school. For information regarding PA, the International Physical Activity Questionnaire (IPAQ short-version) was used. For PAL classification the adolecents who had 300 minutes/week or more of physical activity were considered as active. The information related to the participation in sports schools was obtained through a question inserted in IPAQ. For the academic performance, the average grades of the first semester of 2015 were used, within the three major Knowledge Areas, as defined by the National Curriculum Standards. There was no significant correlation between academic performance and PA $(r=0.06 ; p=0.28)$. Higher minimum scores were found among active high school students and higher average school for areas $1-$ Languages, Codes and its Technologies $(7.2 \pm 0.8)$ and $2-$ Natural Sciences, Mathematics and its Technologies $(6.6 \pm 1.3)$ among participants in sports schools, with statistical significance ( $p=0.017 ; p=0.014$ ). In conclusion, PAL did not relate to the academic performance of pupils in this study and participants of sports schools achieved better academic performance demonstrating that sports activities can cause beneficial effects in their cognitive performances.
\end{abstract}

Keywords: Education; Sports; Adolescents; Behavior.

RESUMO

Ainda existem dúvidas sobre os reais benefícios da atividade física no desempenho acadêmico de adolescentes. $O$ objetivo deste estudo foi determinar se a atividade física $(A F)$ se relaciona ao desempenho acadêmico de alunos do ensino médio. O estudo incluiu 348 adolescentes de uma escola pública federal. Para obter informaçôes sobre AF, utilizou-se o Questionário Internacional de Atividade Física (versão curta IPAQ). Para a classificação do NAF os estudantes com mais de 300 minutos/semana de atividade física e insuficientemente ativos, os estudantes com menos de 300 minutos/semana de atividade física. A informação relacionada à participação em escolas esportivas foi obtida através de uma pergunta inserida no IPAQ. Para o desempenho acadêmico foi utilizada a média das notas do primeiro semestre de 2015, dentro das três grandes Áreas de Conhecimento, definidas pelos Parâmetros Curriculares Nacionais. Não houve correlação significativa entre o desempenho acadêmico e $A F(r=0.06 ; p=0.28)$. Notas minimas superiores foram encontrados entre os escolares ativos $e$

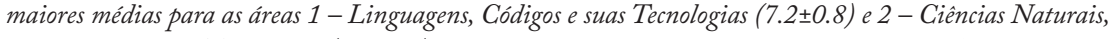
Matemática e suas Tecnologias (6.6 \pm 1.3$)$ entre participantes em escolas esportivas, com significância estatística ( $p=0.017 ; p=0.014)$. Em conclusão, o NAF não se associou negativamente no desempenho acadêmico dos escolares desse estudo e os participantes de escolas esportivas alcançaram melhor desempenho acadêmico, demonstrando que a prática esportiva pode ocasionar efeitos benéficos no desempenho cognitivo.

Palavras-chave: Educação; Esportes; Adolescentes; Comportamento.

\section{Introduction}

There have been a growing number of studies suggesting that regular physical activity $(\mathrm{PA})$ promotes positive impacts beyond those related to the physical health of the individual. Evidences suggest relationship between PA and academic performance in school during childhood and adolescence ${ }^{1-3}$, triggered by the positive impacts that the PA has on mood, memory, concentration and behavior in the classroom ${ }^{4}$.
A study with American school children found a significant relationship between strength components and muscular endurance with higher grades and academic performance associated with physical activity of vigorous intensity ${ }^{5}$. In another research ${ }^{1}$, besides endurance (muscle resistance), a higher correlation coefficient was observed with aerobic fitness, in boys who were in the 'Healthy Fitness Zone' for aerobic conditioning and muscle strength. They were 2.5 to 3 times 
more likely to get better results in Math and Reading. In girls, these values were slightly higher, because those who were in the 'Healthy Fitness Zone' were 2 to 4 times more likely to have good academic performance.

In Portugal, those students who had higher fitness levels, showed a trend of obtaining higher scores. Although females did not present this trend with such evidence, the students with lower levels of physical fitness showed the worst results in their academic performanc$\mathrm{es}^{6}$. Thailandese school students participated in a study ${ }^{7}$ in which researchers reported that the improved cardiovascular fitness showed stronger longitudinal relationship with academic performance, although they did not find direct associations between physical fitness and academic performance. Corroborating these findings, a study with students from Finland ${ }^{8}$ found that adolescents who had high levels of academic performance and reasonable time spent in sedentary behaviors had two times a greater chance of having better school performance when compared to their sedentary peers.

In Brazil, there are few researches on the relationship between PA levels with academic performance. A survey of 226 students in the city of Ilhabela revealed an association between muscle strength of lower limbs and school performance in the discipline of science ${ }^{9}$. A study in Pelotas, which aimed to examine the associations between physical activity with academic and cognitive performance, found that teens, who are active at moderate levels, tend to have superior cognitive performance ${ }^{10}$.

However, although evidence suggests that participation in $\mathrm{PA}$ is positive for the academic performance, some studies have found no results corroborating with these ideas ${ }^{7,11,12}$, which makes controversial the presence of this relationship ${ }^{13}$. In order to extend these discussions, the aim of this study was to determine whether PA is related to academic performances of high school students.

\section{Methods}

\section{Participants}

Three hundred and seventy-seven students enrolled in high school (1st, 2nd and 3rd years) of a federal public school were invited to participate in this cross-sectional study, in the city of Santa Maria, Rio Grande do Sul. The inclusion criteria adopted were: to be regularly enrolled in high school, to present the Consent Form signed by parents or guardians and also by the student and to answer the research instruments. Of the $377 \mathrm{pu}^{-}$ pils enrolled, 348 (92.3\%) met these criteria, which is the final number of participants in the study.

\section{Procedures}

After contacting the school direction in order to request the authorization to carry out the study on the premises, there was contact with the research subjects to give them information about the study objectives, how the data collection would occur and request them to take home to their parents the Consent Form to be signed by them. The work was conducted within the ethical standards of Helsinki Declaration of 1964 and according to the resolution 466/12 of the Ministry of Health. The study was approved by the Research Ethics Committee of the Federal University of Santa Maria, with the protocol number 45388715.0.0000.5346.

For information regarding time spent in PA, the International Physical Activity Questionnaire (IPAQ short-version), validated for use in adolescents ${ }^{14}$, was used. For the interpretation of the results, the time spent in PA was stratified in two groups: active for those that spent 300 minutes per week or more in PA and insufficiently active for those who spent less than 300 minutes per week in $\mathrm{PA}^{15}$. It was also asked if they participated in sports at school groups. The sports are offered by the educational institution during school day and develop training activities in athletics, basketball, futsal, field soccer, handball, volleyball, orienteering and modern triathlon. Data collection regarding PA levels was held in June 2015 in the last week of school before school recess, during the periods allocated for physical education classes. The IPAQ was administered to all students at the same time in the school auditorium, since it is a self-applied questionnaire.

The data relating to academic performance of each pupil were obtained from the Technical Section of the institution, sector responsible for feeding the computerized system in which students' grades are recorded, and made available to researchers in the return of the school break (July/2015), after being computed the academic evaluations of the first semester.

The individual scores obtained at the end of the first semester of 2015 were used, including the three major Knowledge Areas, as defined by the National Curriculum Parameters (NCP) ${ }^{16}$ and distributed as follows: Area 1 - Languages, Codes and its Technologies: comprises the disciplines of Portuguese language, Literature, Arts, Modern Foreign language and Physical Education; Area 2 - Natural Sciences, Mathematics 
and its Technologies: encompasses Biology, Chemistry, Physics and Mathematics; Area 3 - Human Sciences and its Technologies: includes the disciplines of History, Geography, Sociology and Philosophy.

The final score of the first semester was composed of the sum of periodic grades (PG) of the first two marking periods. The PG is composed by the grade of the partial assessments (PAs) plus the evaluation grade (EG) of the study, divided by two: $\mathrm{PG}=(\mathrm{PAs}+\mathrm{EG}) / 2$. PAs checks what is carried out immediately after the end of a subject or content, research works, exercises or other unique teacher discretion instrument. The EG is the formal evaluation event, held at the end of two months and includes all the content worked in the bimester ${ }^{17}$. The academic performance grades range from 0 to 10 points.

\section{Data Analysis}

The data distribution curve was analysed through the Kolmogorov-Smirnov test. Descriptive analysis was performed (average, minimum and maximum values, frequencies and percentage) in the characterization of the study population. After that, the Mann Whitney test was used to check the possible difference between the means of academic performance in the three Knowledge Areas among the groups stratified as active or insufficiently active. The Spearman test was used for correlations analyses between time spent in PA and academic performance, which were performed using the Statistical Analysis System (S.A.S), version 9.2 and GraphPad Prism 5, version 5.01. The significance level was $5 \%(\mathrm{p}<0.05)$.

\section{Results}

The study included the total of 348 students enrolled in high school, $53.2 \%$ males and $46.8 \%$ females, with a mean age of $16.28 \pm 1.07$ years old, ranging from 14 to 19 years old. From all the students, $7.7 \%$ refused to participate in the study or were not present on the day the data collection instruments were applied.

PA presented variability amplitude between zero and 2.250 minutes per week. More than half of the subjects were considered physically active and a third of them participate in sports schools. Table 1 characterizes the study population stratified by high school year, PA level and participation in sports.

The students' academic performances were analyzed by the average grades for each subject that composes the Knowledge Areas recommended by the NCP. The correlation between variables was positive for area 3 and negative for areas 1 and 2, however, not statisticaly significant (Table 2). Similarly, no differences were found between the means of academic performance analyzed considering the PA levels. Table 3 shows the comparisons between each area`s means, stratified by time spent in PA weekly and participation or not in sports schools.

Even though no statistically significant difference was found in the academic performance between the active and insufficiently active groups, it is clear that the minimum score of the active group was higher than that of the inactive group in Area 1. For top marks, both groups were able to achieve scores higher than 9.0.

Differences were found in the average academic performance of Areas 1 and 2, when comparing the participants and non-participants in sports schools. Underlining this result, the minimum marks obtained by the participants in sports schools in these areas were higher than the ones in the non-participants group. With regard to maximum scores, the pattern of academic performance remained similar to the one obtained in PA level, with rates above 9.0 points. Con-

Table 1 - Characterization of students stratified per high school year, Physical Activity Level and participation in sports schools $(n=348)$.

\begin{tabular}{|c|c|c|}
\hline Variables & $f$ & $\%$ \\
\hline \multicolumn{3}{|l|}{ High school year } \\
\hline 1st year & 139 & 39.9 \\
\hline 2nd year & 116 & 33.3 \\
\hline 3rd year & 93 & 26.8 \\
\hline \multicolumn{3}{|c|}{ Physical activity level - PAL } \\
\hline Active & 204 & 58.6 \\
\hline Insufficiently active & 144 & 41.4 \\
\hline \multicolumn{3}{|c|}{ Participants in sports schools } \\
\hline Yes & 112 & 32.2 \\
\hline No & 236 & 67.8 \\
\hline
\end{tabular}

f: frequency; \%: percentage. 
Table 2 - Correlation between the overall average in knowlwdge areas and PA among high school students $(\mathrm{n}=348)$.

\begin{tabular}{lcc}
\hline & Learning Area & Physical activity \\
\cline { 2 - 3 } & $\mathrm{p}$ & $\mathrm{r}$ \\
\hline Global (all 3 areas together) & -0.06 \\
A1 - Languages, Codes and their Technologies & -0.03 \\
A2 - Natural Sciences, Mathematics and its Technologies & 0.55 & -0.10 \\
A3 - Human Sciences and its Technologies & 0.06 & 0.03 \\
\hline
\end{tabular}

$\mathrm{A} 1=\operatorname{area} 1 ; \mathrm{A} 2=\operatorname{area} 2 ; \mathrm{A} 3=\operatorname{area} 3$.

Table 3 - Performance by knowledge area, stratified by their PA levels and participation in sports schools $(n=348)$.

\begin{tabular}{|c|c|c|c|c|c|c|c|}
\hline \multirow{2}{*}{\multicolumn{2}{|c|}{ Knowledge área ${ }^{\dagger}$}} & \multicolumn{3}{|c|}{ Physical Activity } & \multicolumn{3}{|c|}{ Sports Schools } \\
\hline & & \multirow{2}{*}{$\begin{array}{c}\geq 300 \mathrm{~min} / \text { weekend } \\
\text { (active) }\end{array}$} & \multirow{2}{*}{$\begin{array}{c}\begin{array}{c}<300 \mathrm{~min} / \text { weekend } \\
\text { (insufficiently active) }\end{array} \\
7.2 \pm 0.9\end{array}$} & \multirow{2}{*}{$\begin{array}{c}\mathrm{p} \\
\text { value }\end{array}$} & Participants & \multirow{2}{*}{$\begin{array}{c}\text { Non } \\
\text { Participants }\end{array}$} & \multirow{2}{*}{$\begin{array}{c}\begin{array}{c}\mathrm{p} \\
\text { value }\end{array} \\
0.017^{*}\end{array}$} \\
\hline & $\mathrm{X}$ & & & & $7.2 \pm 0.8$ & & \\
\hline \multirow[t]{3}{*}{ A1 } & Min. & 5.4 & 4.7 & & 5.7 & 4.6 & \\
\hline & Max. & 9.2 & 9.2 & & 9.2 & 9.2 & \\
\hline & $\mathrm{X}$ & $6.3 \pm 1.4$ & $6.3 \pm 1.4$ & 0.85 & $6.6 \pm 1.3$ & $6.2 \pm 1.4$ & $0.014^{*}$ \\
\hline \multirow[t]{3}{*}{ A2 } & Min. & 3.4 & 3.4 & & 4.1 & 3.4 & \\
\hline & Max. & 9.5 & 9.6 & & 9.4 & 9.6 & \\
\hline & $\mathrm{X}$ & $6.7 \pm 1.1$ & $6.6 \pm 1.2$ & 0.62 & $6.8 \pm 1.1$ & $6.6 \pm 1.2$ & 0.070 \\
\hline \multirow[t]{2}{*}{ A3 } & Min. & 4.0 & 4.3 & & 4.0 & 4.3 & \\
\hline & Max. & 9.3 & 9.5 & & 9.5 & 9.5 & \\
\hline
\end{tabular}

tgrades between 0 and 10 points; A1: Languages, Codes and its Technologies; A2: Natural Sciences, Mathematics and its Technologies; A3: Human Sciences and its Technologies; X: average; Min: minimum; Max: maximum; Insuf: insufficiently; p value $<0.05$ for the Mann Whitney test.

trary to what happened in areas 1 and 2 , area 3 did not report any difference between the averages of active and inactive students, and it showed higher minimum grades, both in the inactive group and among those who did not participate in sports schools.

\section{Discussion}

It was not possible to stablish a significant correlation between PA and academic performance in this study, and the participants in sports schools presented a better performance in Areas 1 - Languages, Codes and its Technologies - and 2 - Natural Sciences, Mathematics and its Technologies - compared to those who did not engage in sports schools.

Results that don't show any relation between PA and academic performance have also been shown in other studies ${ }^{18,19}$. In an investigation with Iranian boys, Kalantari and Esmaeilzadeh ${ }^{11}$ found no significant relationship between school performance and PA, although the results were positive for aerobic conditioning. The results found by LeBlanc et al. ${ }^{20}$ also did not support the hypothesis that higher PA is related to better academic performance.

Although no significance was observed between the variables, a negative correlation was shown for areas 1 and 2, suggesting that the higher the academic performance, the lower the PA level. This result may be justified by the fact that academic success within the studied institution is valued more than in other schools, including awards and the distinction at the end of each quarter to students with the best academic performances within each class. The personal desire to achieve better grades may be limiting the time for involvement in PA. Pressure for academic success within the educational institutions leads the school to spend more time with areas such as Mathematics and Languages at the expense of being physically active ${ }^{2}$.

Beside that, the particularities inherent to the school's education system, requires the students to use a longer time to prepare to go to school, which includes taking care of their uniforms, hair up for girls, and for boys it should be trimmed every two weeks and the beard must be shaved daily. These factors, coupled with the fact that the displacement is carried out by school transport, submit the students to a longer and tiring journey (over $6 \mathrm{~h} / \mathrm{d}$ ), which makes the days too short to perform many tasks, requiring them to prioritize some activities.

However, some teens choose to prioritize PA, which can lead to less time available to perform schoolwork and to study. Thus, the PA takes the time that could be used carrying out these and other educational readings, and this can interfere in their academic performanc$\mathrm{es}^{10,11}$. Teenagers who provided more than 2.5 hours a day of physical practice were more likely to academic 
failure, suggesting that overtime attributed to PA may affect school performance ${ }^{10}$.

The regular practice of $\mathrm{PA}$ in adolescents has been widely discussed in the literature, generating consensus about its benefits. However, at school, this understanding does not support the prioritization of $\mathrm{PA}$, besides the class periods for physical education. School managers and teachers from other disciplines, often concerned about the exam evaluations of educational institutions, such as the Basic Education Development Index - IDEB and the National High School Exam - ENEM, prioritize increasing workload of subjects like Math and Portuguese, over the periods for physical education, which is sometimes the only time that the students have the opportunity to perform PA.

It is important to highlight that in spite of all evidences shown in this study, the literature indicates that there is a link between academic performance and better physical fitness ${ }^{3-5}$ and good aerobic capacity ${ }^{1,21}$. The intensity of the PA also appears to influence the academic performance ${ }^{8,10,22}$. A recent systematic review ${ }^{23}$ showed the existence of a positive association between measures of cognition and the practice of PA. Thus, a different analysis was proposed in this study, in which tha differences between the active and insufficiently students were considered, as well as the between the participants in sports schools and non-participants.

Although higher grades were related to lower $\mathrm{PA}$, and no difference was seen between the average scores of active and insufficiently active students, the evaluation of the minimum and maximum scores for each area encourages a few thoughts. Both groups of students, considered active and insufficiently active, achieved similar top grades, which were higher than 9.0 points. Regarding the minimum score obtained in area 1, a slight superiority in active students was found. American students who received an extra hour of academic instruction per day did not show higher scores compared with those who were enrolled in physical education classes; however, higher grades were associated with performing vigorous $\mathrm{PA}^{21}$.

Among the most active pupils, the highest scores were found in area 2, which includes Mathematics, and the lowest scores were similar between the active and insufficiently active students. According to Chen et al. ${ }^{7}$, cross-sectional studies report that cardiovascular fitness is positively related to the global academic performance and the relationship may be stronger for Math than for Reading. Although another methodology was used, the study of Chomitz et $\mathrm{al}^{3}$, when ex- amining the relationship between the components of physical fitness with evaluative tests in Mathematics and English, found a positive correlation of Reading and Math with the aerobic capacity of adolescents and good physical fitness increased by $24 \%$ the chances of passing the English test. It is noteworthy that, in this study, Reading and English are part of knowledge area 1, where higher minimum scores were found.

Significant results were found when analyzing the differences between the average academic performance of participants and non-participants in sports schools, for areas 1 and 2, including higher minimum grades for the participants and similar maximum grades. However, in the case of grades ranging from 0 to 10 points, the lag of two-tenths or four-tenths appears to translate the significance found, since the difference is small. Further investigation also showed the power of sport in academic achievement ${ }^{24}$ and higher average grades among teens that practiced sports ${ }^{25}$.

Corroborating the findings of this study, Kantomaa et al. ${ }^{8}$ in a recent survey of more than 8.000 Finnish adolescents, concluded that participation in organized PA, such as sports clubs, were positively associated with their academic performances. It may be justified by the fact that their involvement in these organized activities allows them to develop the ability to listen and follow rules, and choose courses of actions that are appropriate for certain situations that arise during sports practices.

It is noteworthy that the sports clubs of the studied school are offered when the students are not in class and are free of charge. In addition to facilitating the participation of that teenager who prioritizes the PA practice through sport, the student who is already academically successful can enjoy the easy opportunity to access a suitable environment for sports. This can also be considered a justification for the better academic performance among participants in sports schools, going back to what was described by Chen et al. ${ }^{7}$.

Another possible basis for the better academic performance of participants in sports schools can be found in the fact that the activities in sports clubs within the school have vigorous intensity and this seems to be an important factor in increasing school performance. American students who participated in vigorous activities during a semester had better academic results compared to students who did not perform any vigorous activity $^{21}$. An intervention performed with 48 Greek students also showed the beneficial effects that high intensity seems to exert on cognitive performance, and it was suggested that the day should begin with high 
intensity PA to obtain a better performance during the day $^{26}$. An increased PA during the school day may reduce boredom, leading to an increase in the student's capacity for attention and concentration, benefiting the academic performance ${ }^{27}$.

The sports schools of the studied institution, actively participate in competitions, in municipal, state and national levels, and this fact may lead to the development of a training with greater intensity. In the study conducted by Coe et al. ${ }^{21}$, participants who attained higher levels of vigorous activity were those who participated in sports activities. In the longitudinal study developed by Marsh and Kleitman ${ }^{28}$, the participation in sports in high school had positive effects in the academic performance during the school year, providing increased self-esteem, better aspirations and educational and occupational achievements.

Still, according to Trudeau and Shepard ${ }^{29}$, the literature shows that the benefits of sport for the academic performance are more likely to be achieved if offered within the school context, taking advantage of educational resources and environment. It is noted that in addition to the benefits of sport for the academic performance, sports skills acquired in childhood and adolescence can be the best way to ensure the practice of PA during adulthood ${ }^{30}$.

Some limitations in the development of this study should be noted: the fact that the used questionnaire is self-applied can lead to loss of more precise information, despite the detailed guidance to students on completing it, and the lack of data concerning socioeconomic status and parental education should not be taken for granted, since these are information that can interfere with the analysis and discussion of the results. Although there are limitations, this is the first research which sought to establish the relationship between PA levels and the academic performance of students, within the 3 major areas of knowledge advocated by NCP, helping in the discussion of future investigations.

There was no significant correlation between PA level and the academic performance and no difference between active and insufficiently active students, leading to the conclusion that the level of PA did not have any effect on the academic performance of students in this study. The participants of sports schools achieved better academic performance, demonstrating the beneficial effects of sports on the cognitive performance.

Knowing that regular PA does not seem to cause losses for academic performance and being aware of of all positive benefits it has in the health of adolescents, the support and assistance of school managers and teachers in creating effective mechanisms and actions aimed at increasing the adolescents` PA levels are very important. The physical education classes contribute to this increase and may be the right moment to develop awareness of the importance of the positive effects of PA and sports, in addition to health benefits. Whereas adolescents spend much of the day at school, this seems to be the adequate space to provide the awakening and promote among school children the perception that the involvement in sports is an important tool to contribute to their academic achievement.

\section{Competing interests}

The authors declare that they have no competing interests.

\section{Authors' contributions}

Pandolfo KCM, conceived the study, carried out the the experiments, performed the data processing and statistical analysis, and drafted the manuscript; Azambuja CR, participated in its design and coordination and helped to draft the manuscript; Minuzzi M, helped to draft the manuscript; Santos DL, was the advisor, wrote the English version and reviewed tha manuscript. All authors have read and approved the final version of the manuscript, and agree with the order of presentation of the authors.

\section{Reference}

1. Bass RW, Brown DD, Laurson KR, Coleman MM. Physical fitness and academic performance in middle school students. Acta Paediatr. 2013;102(8):832-7.

2. Singh A, Uijtdewilligen L, Twisk JW, Van Mechelen W, Chinapaw MJ. Physical activity and performance at school: a systematic review of the literature including a methodological quality assessment. Arch Pediatr Adolesc Med. 2012;166(1):49-55.

3. Chomitz VR, Slining MM, Mcgowan RJ, Mitchell SE, Dawson GF, Hacker KA. Is there a relationship between physical fitness and academic achievement? Positive results from public school children in the northeastern United States. J Sch Health. 2009;79(1):30-7.

4. Van Dusen DP, Kelder SH, Kohl HW, Ranjit N, Perry CL. Associations of Physical Fitness and Academic Performance Among Schoolchildren. J Sch Health. 2011;81(12):733-40.

5. Coe DP, Peterson T, Blair C, Schutten MC, Peddie H. Physical fitness, academic achievement, and socioeconomic status in school-aged youth. J Sch Health. 2013;83(7):500-7.

6. Costa C, Rodrigues LP, Carvalho GS. Influência da aptidão física e morfológica no sucesso académico: um estudo longitudinal retrospectivo. 2011. In: B. Pereira e G.S. Carvalho (Coord.). Atas do VII Seminário Internacional de Educação Física, Lazer e Saúde: A atividade física promotora de saúde e desenvolvimento pessoal e social. CIEC, Instituto de Educação, Universidade do Minho: pp.1363-1383. [ISBN: 978-989-8537-00-3].

7. Chen L, Fox KR, Ku PW, Taun CY. Fitness change and subsequent academic performance in adolescents. J Sch Health. 2013;83(9):631-8. 
8. Kantomaa MT, Stamatakis E, Kankaanpää A, Kajantie E, Taanila A, Tammelin T. Associations of Physical Activity and Sedentary Behavior With Adolescent Academic Achievement. J Res Adolesc. 2015;26(3):432-42.

9. Ferrari GLDM, Rezende LFM, Bezerra DR, Araújo TL, Matsudo VKR. Associação da aptidão física e desempenho acadêmico de escolares. R Bras Ci Mov. 2014;22(4):37-46.

10. Esteban-Cornejo I, Hallal PC, Mielke GI, Menezes AM, Gonçalves H, Wehrmeister F, et al. Physical Activity throughout Adolescence and Cognitive Performance at 18 Years of Age. Med Sci Sports Exerc. 2015;47(12):2552-7.

11. Kalantari $H$, Esmaeilzadeh $S$. Association between academic achievement and physical status including physical activity, aerobic and muscular fitness tests in adolescent boys. Environ Health Prev Med. 2015;21(1):27-33.

12. Alexander R, Hay JA, Liu J, Faught BE, Engemann J, Cairney $\mathrm{J}$. The influence of aerobic fitness on the relationship between academic performance and motor proficiency. Univers J Pub Health. 2015;3(4):145-52.

13. Von Hippel PT, Bradbury WK. The effects of school physical education grants on obesity, fitness, and academic achievement. Prev Med. 2015;78:44-51.

14. Guedes DP, Lopes CC, Guedes JERP. Reprodutibilidade e validade do Questionário Internacional de Atividade Física em adolescentes. Rev Bras Med Esporte. 2005: 11(2);151-58.

15. Strong WB, Malina RM, Blimkie CJ, Daniels SR, Dishman RK, Gutin B, et al. Evidence based physical activity for school-age youth. J Pediatr. 2005;146(6):732-7.

16. Brasil. PCN - Parâmetros Curriculares Nacionais. 2000. Available in:url:http://portal.mec.gov.br/acompanhamento-dafrequeencia-escolar/195-secretarias-112877938/seb-educacaobasica-2007048997/12598-publicacoes-sp-265002211. Access 17 ago. 2017.

17. Brasil. NIAE - Normas Internas para Avaliação Educacional. 2009. Available in: url:http://www.depa.ensino.eb.br/ . Access 17 ago 2017.

18. Tremblay MS, Inman JW, Willms JD. The relationship between physical activity, self-esteem, and academic achievement in 12-year-old children. Pediatr Exerc Sci. 2000;12(3):312-23.

19. HuangTT,Goran MI,Spruijt-MetzD.Associations of adiposity with measured and self-reported academic performance in early adolescence. Obesity. 2006;14(10):1839-45.
20. Leblanc MM, Martin CK, Han H, Newton JR, Sothern M, Webber LS, et al. Adiposity and physical activity are not related to academic achievement in school-aged children. J Dev Behav Pediatr. 2012;33(6):486-94.

21. Coe DP, Pivarnik JM, Womack CJ, Reeves MJ, Malina RM. Effect of physical education and activity levels on academic achievement in children. Med Sci Sports Exerc. 2006;38(8):1515-9.

22. Rombaldi AJ, Clark VL, Reichert FF, Araújo CL, Assunção MC, Menezes AM, et al. Incidence of school failure according to baseline leisure-time physical activity practice: Prospective study. J Adolesc Health. 2012;51(6):S22-6.

23. Mota J, Picado A, Assunção T, Alvito A, Gomes F, Marques A. Atividade Física e Rendimento Acadêmico: Uma Revisão Sistemática de Sete Revisões Sistemáticas.J Sport Pedag Res. 2015;1(6):24-9.

24. Cornelisen T, Pfeifer $\mathrm{C}$. The impact of participation in sports on educational attainment: New evidence from Germany. Econ Educ Rev. 2010;29(1):94-103.

25. Fox CK, Barr-Anderson D, Neumark-Sztainer D, Wall M. Physical activity and sports team participation: Associations with academic outcomes in middle school and high school students. J Sch Health 2010;80(1):31-7.

26. Travlos AK. High intensity physical education classes and cognitive performance in eighth-grade students: an applied study. Intel J Sport Exerc Psychol. 2010;8(3):302-11.

27. Shephard RJ. Habitual physical activity and academic performance. Nutr Rev. 1996;54(4):S32.

28. Marsh HW, Kleitman S. School athletic participation: Mostly gain with little pain. J Sport Exerci Psychol. 2003;25(2):205-28.

29. Trudeau F, Shephard RJ. Physical education, school physical activity, school sports and academic performance. Int J Behav Nutr Phys Act. 2008;5(10):1-12.

30. Tammelin T, Näyhä $S$, Hills AP, Järvelin MR. Adolescent participation in sports and adult physical activity. Am J Prev Med. 2003;24(1):22-8.

\section{Quote this article as:}

Pandolfo KCM, Minuzzi T, Azambuja CR, Santos DL. Physical activity and academic performance in high school students. Rev Bras Ativ Fís Saúde. 2017; 22(5):486-92. DOI: 10.12820/rbafs. v.22n5p486-92.

Recebido: $17 / 09 / 2017$

Aprovado: 22/12/2017 